\begin{tabular}{c} 
Volume and Issues Obtainable at Center for Sustainability Research and Consultancy \\
Journal of Accounting and Finance in Emerging Economies \\
ISSN: 2519-0318 ISSN (E) 2518-8488 \\
Volume 6: Issue 4 December 2020 \\
CSRC \\
Journal homepage: www.publishing.globalcsrc.org/jafee \\
\hline
\end{tabular}

\title{
Impact of Behavioral Biases on Investment Performance in Pakistan: The Moderating Role of Financial Literacy
}

\begin{tabular}{|c|c|}
\hline \multicolumn{2}{|c|}{ 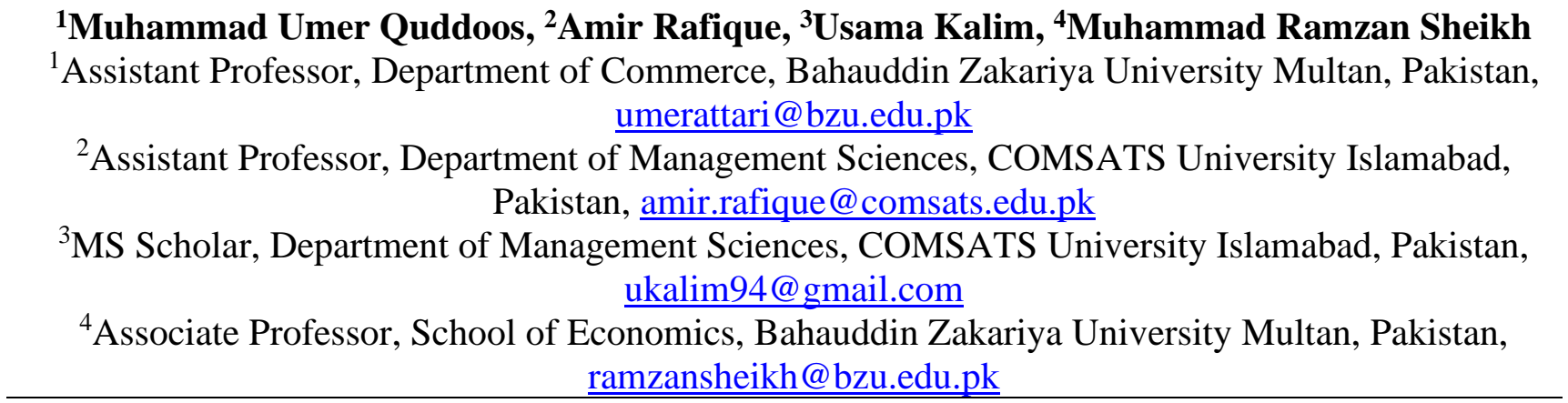 } \\
\hline ARTICLE DETAILS & ABSTRACT \\
\hline $\begin{array}{l}\text { History } \\
\text { Revised format: November } \\
2020 \\
\text { Available Online: December } \\
2020\end{array}$ & $\begin{array}{l}\text { This study aims at understanding the relationships of certain } \\
\text { behavioral biases with the investment performance, and identifies } \\
\text { the moderating role of financial literacy upon these hypothesized } \\
\text { relationships. Data is collected through questionnaire from the } \\
\text { investors trading at Pakistan Stock Exchange (PSX). Structured }\end{array}$ \\
\hline $\begin{array}{l}\text { Keywords } \\
\text { Stock Exchange, Behavioral } \\
\text { Biases, Investment } \\
\text { Performance, Financial } \\
\text { Literacy }\end{array}$ & $\begin{array}{l}\text { Equation Modeling (SEM) is used to analyze the data with the } \\
\text { results that only anchoring and overconfidence biases have } \\
\text { significant effects on investment performance. The results also show } \\
\text { that presence of financial literacy does not play any role in } \\
\text { improving the performance of investors. Majorly, findings of current }\end{array}$ \\
\hline $\begin{array}{l}\text { JEL Classification: } \\
G 40, G 41\end{array}$ & $\begin{array}{l}\text { ing the moderating role of financial literacy } \\
\text { l biases and the outcome of investment } \\
\text { ected to be useful for investors and policy }\end{array}$ \\
\hline
\end{tabular}

\section{OPEN ACCESS}

(C) 2020 The authors, under a Creative Commons Attribution-

NonCommercial 4.0

Corresponding author's email address: ramzansheikh@bzu.edu.pk

Recommended citation: Quddoos, M. U., Rafique, A., Kalim, U. \& Sheikh, M. R. (2020). Impact of Behavioral Biases on Investment Performance in Pakistan: The Moderating Role of Financial Literacy. Journal of Accounting and Finance in Emerging Economies, 6(4), 1199-1205

\section{Introduction}

Standard finance assumes that investors are rational and make decisions based on risk-return considerations only (Bloomfield, O'hara, and Saar, 2009). However, they do not always follow the standard procedures for investment decision making due to their psychological and behavioral aspects (Cohn, Lewellen \& Schlarbaum, 1975). Investors have several psychological biases, which are against the rational decision-making process (Rubaltelli et al., 2010).

Behavioral finance clarifies the inefficiencies of the markets because it relies on psychological factors affecting investors decision making (Waweru et al., 2008). It explains the market functioning in real 
world and helps to understand and explain the behavior patterns of the investors (Waweru et al., 2008). Behavioral finance explains investors' feelings and cognitive errors that affect investment performance. Proponents of behavioral finance support the argument that study of human psychology is helpful in identifying stock market behaviors and in explaining the reasons of market bubbles and crashes in the real world (Gao \& Schmidt, 2005). So, it helps to understand the role of behavioral biases in the stock market and explain how these biases influence the decisions in the financial markets of the world (Kim \& Nofsinger, 2008).

Though there are several biases which impact upon investors' decision making but we have selected certain major biases which are supposed to influence the investors' behavior in the emerging markets. Jain, Walia, and Gupta (2019) ranked the behavioral biases which influence the investors' decision making in India. Where they applied Fuzzy analytic hierarchy process to rank the factors influencing the retail investors' decision making. They identified that the three most influential biases were herding bias, loss aversion bias and overconfidence bias. We have selected these three biases for investigation and added anchoring bias based on the gap identified as a result of literature review in the context of Pakistan.

Most of the behavioral finance literature is about the developed markets. However, the number of studies on the issue very limited in the context of developing markets. In Pakistan, very limited work is available on behavioral finance. This study attempts to explain the role of some of the most common biases and their effects upon the investment performance. The study also investigates the moderating role of financial literacy in determining performance of investors as the more informed and financially aware investor can achieve better results from exploiting the available opportunities (Clark, Lusardi, \& Mitchell, 2015).

This study has following objectives:

(1) To examine the impact of behavioral biases; overconfidence, loss aversion, anchoring and herding on the performance of investors in Pakistan Stock Exchange (PSX).

(2) To investigate the moderating effect of financial literacy on relationships of behavioral biases; overconfidence, anchoring, loss aversion, herding with the performance of investors at PSX.

\section{Literature Review}

Earlier theories of standard finance like EMH (Efficient Markets Hypothesis) state that securities prices reflect fundamental values, the stock prices in the market are accurately determined by investors. Although, not all investors are fully rational, but according to the theory of EMH, the stock market is fully rational. On the contrary, supporters of behavioral finance believe that the financial markets can never be informationally efficient all the time (Ritter, 2003). There are several biases which affect the investors behavior. The main of these are: overconfidence, loss aversion, anchoring and herding which have a strong bearing upon investors' behavior. Shefrin (2000) argued that overconfidence is the investors' feeling of having more control on the investment decisions. Anchoring is a phenomenon whereby people use past values as the base value for making decisions for future (Kahneman \& Tversky, 1979). This behavior leads to the under and over reaction of the investors to unexpected changes in the market (Waweru et al., 2008). Loss aversion renders investors too conservative in investment decisions that they avoid selling their underperforming stocks with the hope that they will eventually outperform winning stocks in future (Yeoh et al., 2013). Investors try to minimize their risk by turning to the riskfree securities i.e., fixed deposits, bonds, etc. and neglect the inflation factor which can result into negative real returns (Kartasova, 2013). Herding is defined as the benchmarking tendency on the part of investors to follow the larger group of investors (Tan, Chiang, \& Mason 2008).

Investors' biases and sentiments affect the investment decisions thereby creating market-wide bubbles due to the irrational behavior and related actions of investors. Pan (2020) investigated the relationship 
between stock market bubbles and investors' sentiment and found a positive effect of investors' sentiment upon stock bubbles and bubbles' size along with the influence of bubble shocks upon the investors' sentiment. Based on these findings, it can be concluded that the investors' behavior is a key predictor of stock market bubbles.

Individual investors normally involve in biased behavior related to buying and selling decisions, so this study focuses on these investors' decisions, which largely affect the stock market performance. Shefrin and Statman (1985) report that investors sell winning stocks and hold losing stocks, which is basically the "disposition effect" and the behavior is also confirmed by Odean (1998). Odean (1998) also provides great insights about the buying behavior of investors. He concluded in his research that buying decision of investors is due to the "attention effect". Investors tend to invest in those stocks that catch their attention based on their past performances. Therefore, it is concluded that investors' buying or selling decisions are affected by several biases, so these biases eventually impact their performance.

Biases also affect the investor' risk propensity while taking their investment decisions. In a study, Combrink \& Lew (2020) checked the relationships among the risk propensity, overconfidence and undergo bias, but, on the contrary, did not find any significant impact upon the risk propensity. Apart from risk propensity the biases are key determinant of investors' decision-making process. Whereas the impact of each bias might be different on investors and the impact may vary from market to market. There are a few biases which do have more impact than other biases, so this study focuses only on the biases which are critical to the investors' decision-making. In one of the studies on the subject, Madaan and Singh (2019) found that overconfidence and herding bias have significant positive impact on investment decision. In this study, we are analyzing four biases based on an identified gap in the literature in the context of emerging economy of Pakistan. One of the major contributions of this study is incorporation of the moderating role of financial literacy upon the relationships between biases and investment decision.

Researchers in the field of behavioral finance like Anderson, Henker \& Owen (2005) posited that behavioral biases could be helpful for investors in making their investment decisions easily and that the investors are prone to different kinds of biases while making investment related decisions and these decisions can result in either good or bad performance. In the study we will follow the method developed by Oberlechner and Osler (2004) for measuring individuals' investment performance. This method measures the performance by the satisfaction level of individual investors. From the above arguments, hypotheses $\mathrm{H} 1$ to $\mathrm{H} 8$ were proposed for testing in this study:

H1: The Overconfidence bias significantly influences the investment performance.

$\mathbf{H}_{2}$ : Anchoring bias significantly influences the investment performance.

H3: Loss aversion bias significantly influences the investment performance.

H4: Herding bias bias significantly influences the investment performance.

H5: Financial literacy significantly moderates the relationship of investment performance with Over confidence bias.

H6: Financial literacy significantly moderates the relationship of anchoring bias with investment performance.

H7: Financial literacy significantly moderates the relationship of investment performance and loss aversion bias.

Hs: Financial literacy significantly moderates the relationship of investment performance and herding behavior. 


\section{Theoretical Framework}

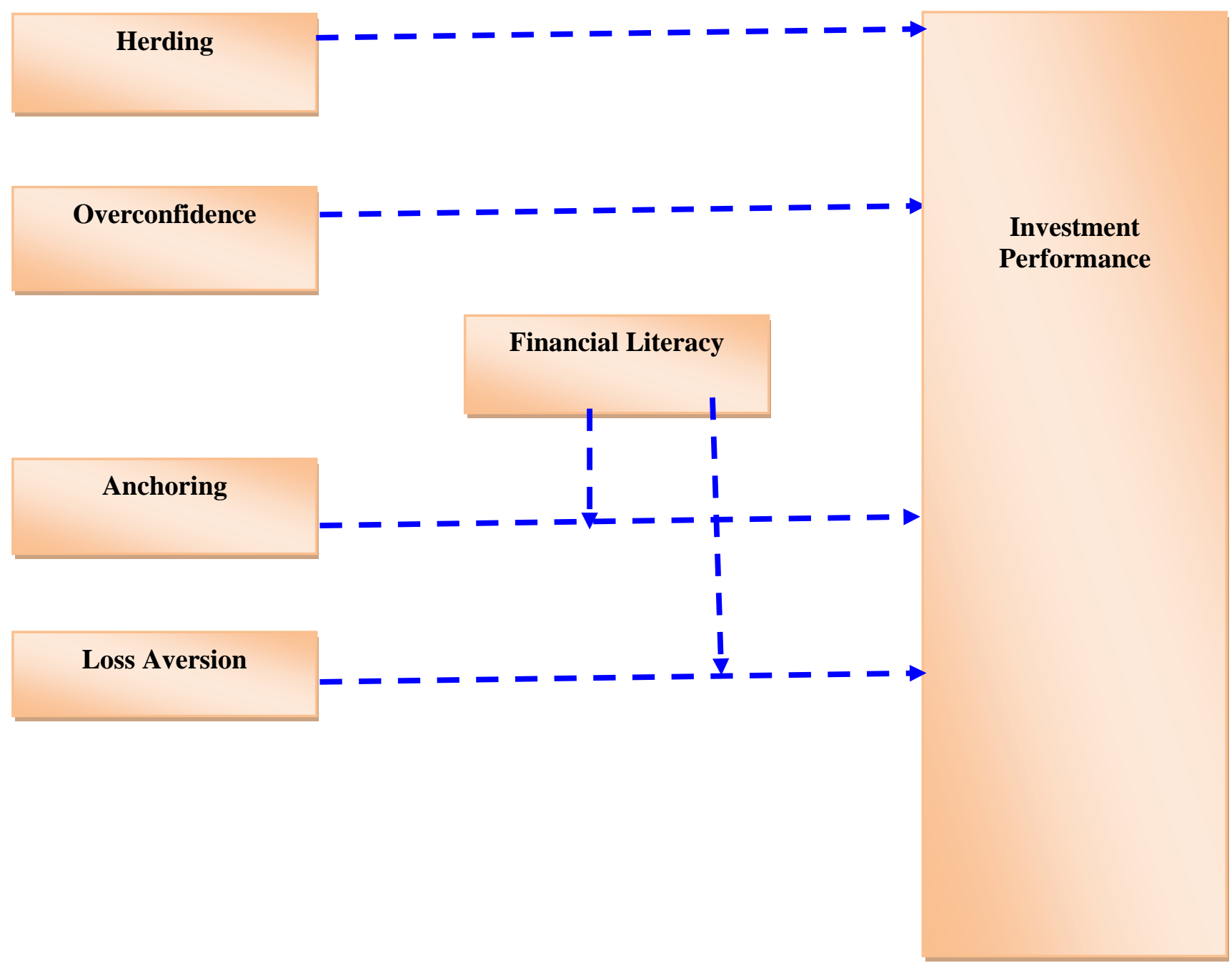

Figure 1: Research Model of the Study

\section{Methodology}

The research design applied in this study is cross-sectional in nature. For the cross-sectional data, a questionnaire was adapted and developed for this study. The questionnaire consists of three parts- first part is about demographic questions; the second part is about all the independent variables such as overconfidence, anchoring, loss aversion, herding, financial literacy and the third part measures the dependent variable which is investment performance. A Five-point Likert scale was used in the study for the responses of the investors excluding basic information part. The scales used to measure Overconfidence (four items), Anchoring (four items) and Loss Aversion (four items) are adopted from the study of Mouna \& Anis (2015). The scale for Herding bias (four items) is adapted from Phuoc Luong (2011). The items for Financial Literacy (seven items) are adapted from Cude et al. (2006). The items for Investment Decision Making (five items) are adopted from Scott \& Bruce (1995). The scale used to measure Investment Performance (three items) is adapted from the study of Phuoc Luong (2011). The responses were collected through convenience sampling. SPSS and AMOS are used for data analysis comprising Structural Equation Modeling (SEM) technique that incorporates both observed and latent variable values for measuring and testing of hypothesized relationships, which is a multivariate technique of structural theory (Tan, 2001). 


\section{Data Analysis}

The demographics show that majority of investors are male because of a low percentage of active female investors at PSX. To analyze the effects of the biases on the performance of investors, results calculated using AMOS are shown in the following Figure 2.

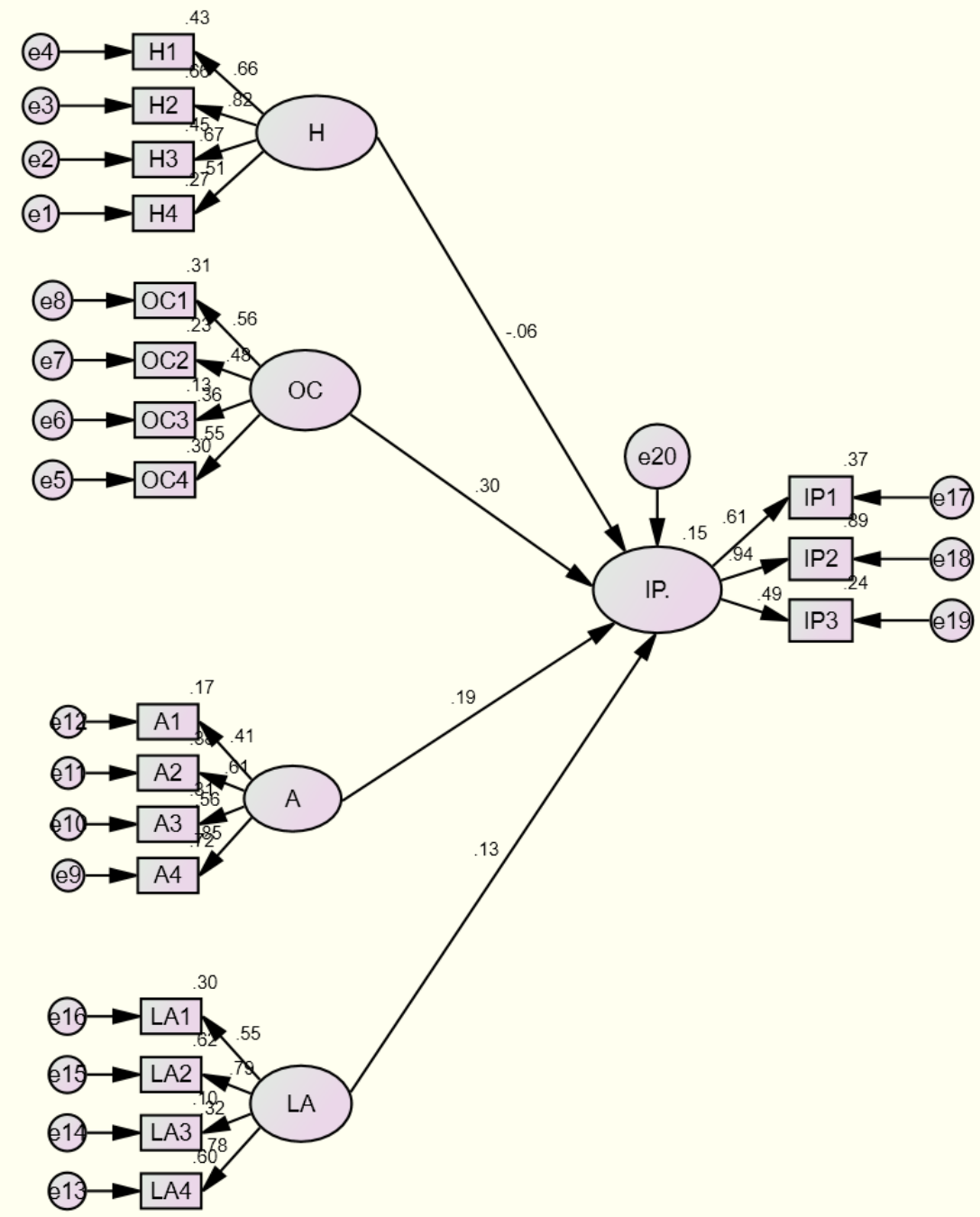

Figure 2. Behavioral Biases and Performance

The detail about the relationships as proposed by hypotheses are shown in the table below:

Table 1. Regression Weights

\begin{tabular}{ll|rrrrr}
\hline & & Estimate & S.E. & C.R. & P & Label \\
\hline IP <--- & Herding & -.067 & .081 & -.834 & .405 \\
IP <--- & Overconfidence & .329 & .118 & 2.795 & .005 & \\
IP <--- & Anchoring & .142 & .060 & 2.392 & .017 & \\
IP <--- & Loss Aversion & .104 & .061 & 1.702 & .890 & \\
\hline
\end{tabular}

Table 2. Standardized Regression Weights

\begin{tabular}{lrl|r}
\hline & & & Estimate \\
\hline Investment Performance & $<---$ & Herding & .062 \\
Investment Performance & $<---$ & Overconfidence & .299 \\
Investment Performance & $<---$ & Anchoring & .190 \\
Investment Performance & $<---$ & Loss Aversion & .130 \\
\hline
\end{tabular}


Table 2 shows that Herding Bias has no significant impact on investment performance. The values $(\beta=-$ $0.062, \mathrm{p}>0.05)$ showing an insignificant relationship between the two variables. It shows in Pakistani market investors cannot make extraordinary returns by following the herd of other investors like in the case of other countries. The value $(\beta=0.299, \mathrm{p}<0.01)$ shows significant association between overconfidence and investment performance. The value $(\beta=0.19, \mathrm{p}<0.05)$ shows that Anchoring bias significantly impacts the performance. Loss Aversion shows no significant relationship with investment performance $(\beta=-0.130, \mathrm{p}>0.05)$.

The results prove that Anchoring and overconfidence variables affects the investment performance positively. The other variables i.e., Herding, and Loss aversion have no effect on investment performance. Although previous researchers (e.g., Phuoch and Loungh, 2011; Ameer and Anum, 2017, Anderson, Henker \& Owen, 2005 and Javeria et. al, 2016) found herding bias to be positively related to investment performance but, on the contrary, in this study no significant relationship of investment performance was found with these biases, except the Heuristics variable which happens to affect the investment performance PSX. One possible reason for these results could be the uncertain economic conditions in the country. Bhowmik (2013) argued that volatile market environment affects the fundamental values of the securities thereby making accurate prediction difficult for the investors. In this study, no moderating role of financial literacy was found upon the hypothesized relationships between the behavioral biases and investment performance. The reason could be the uncertain economic as well as the financial environment of the country, which directly affect the investment performance at PSX. Furthermore, in this study we used Basic Knowledge of Finance (just one dimension) to check the financial literacy of the investors.

\section{Conclusions and Recommendations}

Findings of present study help us in understanding investors' behavior and their effects on investment performance in an emerging market. Investors' performance was not found to be affected by herding and loss aversion behavior. These results contrast with those of previous studies (Phuoch and Loungh, 2011; Ameer and Anum, 2017, Anderson, Henker \& Owen, 2005 and Javeria et. al, 2016) which state that herding could be helpful in improving the investment performance. The heuristic biases like overconfidence and anchoring enable investors to use their judgment and mental shortcuts for quick decisions in an uncertain environment thereby helping them to gain better investment returns in a volatile financial environment like that of Pakistan.

Financial literacy checks and mitigates the irrational behavior in investment decision making and improves their performance (Alessie, 2011; Lusard and Mitchell, 2007; Shakir Ullah, 2015) but this study could not detect any sort of relationship between financial literacy and investment performance. Possible reason for these results may be the fact that just having some basic knowledge of finance is not helping investors in the much uncertain financial environment of PSX. The future research can take care of the gender representation by sampling a greater number of female investors as suggested by Gumus and Dayioglu (2015) that gender also influences investment decisions.

\section{References}

Anderson, A., Henker, J., \& Owen, S. (2005). Limit order trading behavior and individual investor's performance. The Journal of Behavioral Finance, 6(2), 71-89.

Anum, B. A. (2017). Behavioral Factors and their Impact on Individual Investors Decision Making and Investment Performance: Empirical Investigation from Pakistani Stock Market. Global Journal of Management and Business Research.

Bhowmik, D. (2013). Stock market volatility: An evaluation. International Journal of Scientific and Research Publications, 3(10), 1-17.

Bloomfield, R., O’hara, M., \& Saar, G. (2009). How noise trading affects markets: An experimental analysis. The Review of Financial Studies, 22(6), 2275-2302. 
Clark, R. L., Lusardi, A., \& Mitchell, O. S. (2015). Employee financial literacy and retirement behavior: A case study.

Cohn, R. A., Lewellen, W. G., Lease, R. C., \& Schlarbaum, G. G. (1975). Individual investor risk aversion and investment portfolio composition. The Journal of Finance, 30(2), 605-620.

Combrink, S., \& Lew, C. (2020). Potential Underdog Bias, Overconfidence and Risk Propensity in Investor Decision-Making Behavior. Journal of Behavioral Finance, 21 (4), 337351. DOI: $10.1080 / 15427560.2019 .1692843$

Cude, B., Lawrence, F., Lyons, A., Metzger, K., LeJeune, E., Marks, L., \& Machtmes, K. (2006). College students and financial literacy: What they know and what we need to learn. Proceedings of the Eastern Family Economics and Resource Management Association, 102(9), 106-109.

Gao, L., \& Schmidt, U. (2005). Self is never neutral: why economic agents behave irrationally. The Journal of Behavioral Finance, 6(1), 27-37.

Gumus, F. B., \& Dayioglu, Y. (2015). An Analysis on The Socio-Economic and Demographic Factors That Have an Effect on The Risk-Taking Preferences of Personal Investors. International Journal of Economics and Financial Issues, 5(1), 136.

Jain, J., Walia, N. \& Gupta, S. (2019). Evaluation of behavioral biases affecting investment decision making of individual equity investors by fuzzy analytic hierarchy process. Review of Behavioral Finance, 12(3), 297-314. https://doi.org/10.1108/RBF-03-2019-0044

Kahneman, D., \& Tversky, A. (1979). On the interpretation of intuitive probability: A reply to Jonathan Cohen. Cognition, 7(4), 409-411.

Kartasova, J. (2013). Factors forming irrational Lithuanian individual investors' behaviour. Verslo Sistemos ir Ekonomika, 3(1).

Kim, K. A., \& Nofsinger, J. R. (2008). Behavioral finance in Asia. Pacific-Basin Finance Journal, 16(12), 1-7.

Madaan, G., \& Singh, Sanjeet. (2019). An Analysis of Behavioral Biases in Investment DecisionMaking. International Journal of Financial Research 10(4):55-67.

Mouna, A., \& Anis, J. (2015). A study on small investors' sentiment, financial literacy and stock returns: evidence for emerging market. International Journal of Accounting and Economics Studies, 3(1), 10-19.

Odean, T. (1998). Are investors reluctant to realize their losses? The Journal of finance, 53(5), 17751798.

Pan, W., F. (2020). Does Investor Sentiment Drive Stock Market Bubbles? Beware of Excessive Optimism! Journal of Behavioral Finance, 21(1), 27-41. DOI: 10.1080/15427560.2019.1587764

Phuoc, L., \& Thi Thu Ha, D. (2011). Behavioral factors influencing individual investors' decisionmaking and performance.: A survey at the Ho Chi Minh Stock Exchange.

Ritter, J. R. (2003). Behavioral finance. Pacific-Basin finance journal, 11(4), 429-437.

Rubaltelli, E., Pasini, G., Rumiati, R., Olsen, R. A., \& Slovic, P. (2010). The influence of affective reactions on investment decisions. Journal of Behavioral Finance, 11(3), 168-176.

Scott, S. G., \& Bruce, R. A. (1995). Decision-making style: The development and assessment of a new measure. Educational and psychological measurement, 55(5), 818-831.

Shefrin, H. (2000). Recent developments in behavioral finance. The Journal of Wealth Management, 3(1), 25-37.

Shefrin, H., \& Statman, M. (1985). The disposition to sell winners too early and ride losers too long: Theory and evidence. The Journal of finance, 40(3), 777-790.

Tan, K. C. (2001). A structural equation model of new product design and development. Decision Sciences, 32(2), 195-226.

Tan, L., Chiang, T. C., Mason, J. R., \& Nelling, E. (2008). Herding behavior in Chinese stock markets: An examination of A and B shares. Pacific-Basin Finance Journal, 16(1-2), 61-77.

Waweru, N. M., Munyoki, E., \& Uliana, E. (2008). The effects of behavioural factors in investment decision-making: a survey of institutional investors operating at the Nairobi Stock Exchange. International Journal of Business and Emerging Markets, 1(1), 24-41. 